\title{
Chapter 3 \\ Overview of Engineering Mathematics Education for STEM in Russia
}

\author{
Yury Pokholkov, Kseniya Zaitseva (Tolkacheva), Mikhail Kuprianov, \\ Iurii Baskakov, Sergei Pozdniakov, Sergey Ivanov, Anton Chukhnov, \\ Andrey Kolpakov, Ilya Posov, Sergey Rybin, Vasiliy Akimushkin, \\ Aleksei Syromiasov, Ilia Soldatenko, Irina Zakharova, and Alexander Yazenin
}

\footnotetext{
Y. Pokholkov $\cdot$ K. Zaitseva (Tolkacheva)

Association for Engineering Education of Russia (AEER), Tomsk, Russia

e-mail: pyuori@mail.ru

M. Kuprianov · I. Baskakov · S. Pozdniakov $\cdot$ S. Ivanov $(\bowtie) \cdot A$. Chukhnov $\cdot$ A. Kolpakov · V. Akimushkin

Saint Petersburg State Electrotechnical University (LETI), St. Petersburg, Russia

e-mail: mskupriyanov@mail.ru; bosk@bk.ru; sg_ivanov@mail.ru

I. Posov

Saint Petersburg State Electrotechnical University (LETI), St. Petersburg, Russia

Saint Petersburg State University (SPbU), St. Petersburg, Russia

e-mail: i.posov@spbu.ru

S. Rybin

Saint Petersburg State Electrotechnical University (LETI), St. Petersburg, Russia

ITMO University, Department of Speech Information Systems, St. Petersburg, Russia
}
A. Syromiasov
Ogarev Mordovia State University (OMSU), Department of Applied Mathematics,
Differential Equations and Theoretical Mechanics, Saransk, Russia
e-mail: syal1@yandex.ru

\section{Soldatenko $\cdot$ A. Yazenin}

Tver State University (TSU), Information Technologies Department, Applied Mathematics and Cybernetics Faculty, Tver, Russia

e-mail: soldis@yandex.ru; Yazenin.AV@tversu.ru

\section{Zakharova}

Tver State University (TSU), Mathematical Statistics and System Analysis Department, Applied Mathematics and Cybernetics Faculty, Tver, Russia e-mail: zakhar_iv@mail.ru 


\subsection{Review of Engineer Training Levels and Academic Degrees}

Higher education in general and engineering education in particular are divided into three levels in Russia. The first level is the Bachelor's degree course; the second level is the specialist and Master's degree program; the third level is the postgraduate training program.

"The Bachelor's degree" training level was introduced in Russia in 1996. The standard training period to get the Bachelor qualification (degree) is at least 4 years with the total study load volume of 240 credits. The Bachelor qualification is conferred based on the results of a presentation of the graduate thesis at a session of the State Certifying Commission.

In 1993 the term of Master was established in Russia as the qualification of the graduates of educational institutions of higher professional education. The standard period of the Master training program (for the intramural form of study) is currently 2 years with the credit value of the educational program of 120 credits. Before that, however, the student is to complete the Bachelor (4 years) or specialist (5-6 years) training program. The Master's qualification (academic degree) is conferred only after presentation of the Master's thesis at a session of the State Certifying Commission.

The Bachelor's and Master's qualifications (degrees) were historically preceded by the specialist qualification presupposing 5-6 years of continuous learning. In the Soviet Union it was the only possible qualification; but then the gradual transition to the Bachelor and Master levels took place. At present the specialist qualification has been preserved. When a prospective student applies documents to a university he or she may be admitted to a Bachelor or specialist's training program (depending on the selected department, future profession, etc.). Today, however, the specialist qualification is comparatively rare, having receded in favor of the Bachelor's training program. It is conferred based on the results of the presentation of a graduation project or graduation thesis at the session of the State Certifying Commission and gives the right to enter the Master's Degree course (although like the Master's Degree course the specialist degree course is the second level of higher education) and the postgraduate training program.

The postgraduate program is one of the forms of training of top-qualification personnel. Before September 1, 2013 the postgraduate program was one of major forms of training of the academic and scientific personnel in the system of postgraduate professional education. Since September 1, 2013 (the date when the Federal Law No. 273-FZ dated December 29, 2012 "On Education in the Russian Federation" came into force) the postgraduate program was referred to the third level of higher education. The person who has completed the postgraduate program and presented a thesis receives the academic degree of a candidate of the sciences. In the USSR, the Russian Federation (RF) and in a number of Commonwealth of Independent States (CIS) countries this degree corresponds to the Doctor of Philosophy degree $(\mathrm{PhD})$ in western countries. Presentation of a candidate thesis 
is public and takes place in a special dissertation council in one or several related scientific specialties. In many cases the thesis is presented outside of the higher educational institution where the applicant for the degree studied.

A Doctor of Sciences is the top academic degree (after the Candidate of Sciences). In Russia the degree of a Doctor of Sciences is conferred by the Presidium of the Higher Attestation Commission (VAK) of the Ministry of Education and Science of the Russian Federation based on the results of the public presentation of the doctorate thesis in a specialized dissertation council. The applicant for the degree of a Doctor of Sciences is to have the academic degree of a Candidate of Sciences. An approximate analog of the Russian doctoral degree accepted in AngloSaxon countries is the degree of a Doctor of Sciences (Dr. Sc.) or the German Doctor habilitatis degree (Dr. habil.).

\subsection{Forms of Studies of Engineering Students}

Three forms of obtaining education have been traditionally established in Russia: intramural (full-time), part-time (evening time), extramural.

In the intramural form of education the student attends lectures and practical classes every day or almost every day (depending on the timetable). Most classes are held in the morning or in the afternoon (hence the second name).

The evening time form of studies is primarily designed for those students who work during the day. In this connection classes are held in the evening hours. Accordingly, less time is provided for classroom studies and the volume of unsupervised activities increases.

The extramural form of studies presupposes that students meet teachers only during the examination periods which take place 2-3 times a year and are 1-2 weeks long each. During these periods students have classroom studies and take tests and exams; besides, students get assignments which should be done in writing by the beginning of the next examination period. Thus, in the extramural form of studies the contact work with the teacher is minimal and the volume of unsupervised work is maximum.

The new law of education (to be further discussed below) includes new forms of organization of education: on-line learning and remote learning. Network learning presupposes that a student studies some subjects in one higher educational institution and other subjects in another and then gets a "combined" diploma of both institutions. In remote learning the students communicates with the teacher mostly by means of Internet and classes are conducted in the form of a video conference. 


\subsection{Statistics and Major Problems of Engineering Education in Russia}

The Russian Federation has 274 engineering higher educational institutions, training $1,074,358$ students. With account of comprehensive universities also admitting students for engineering training programs the total number of higher educational institutions where a student can obtain engineering education is 560 . The total number of engineering students is about a million and a half. The distribution of engineering students by regions of Russia ${ }^{1}$ is shown on the map in Fig. 3.1. The numbers on the map are described in Table 3.1.

The number of students per 10 thousand inhabitants of the population varies from 78 (East-Siberian region) to 295 (Northwest region) but in other regions the distribution is more uniform, and it varies between 150 and 200 students per 10,000 inhabitants.

The problems of Russian engineering education include:

- Disproportionality between the distribution of higher educational institutions by regions of Russia and the territorial distribution of production facilities.

- Low quality of admission (weak school knowledge of many prospective students).

- Low level of Russian domestic academic mobility.

- Seclusion from international educational networks.

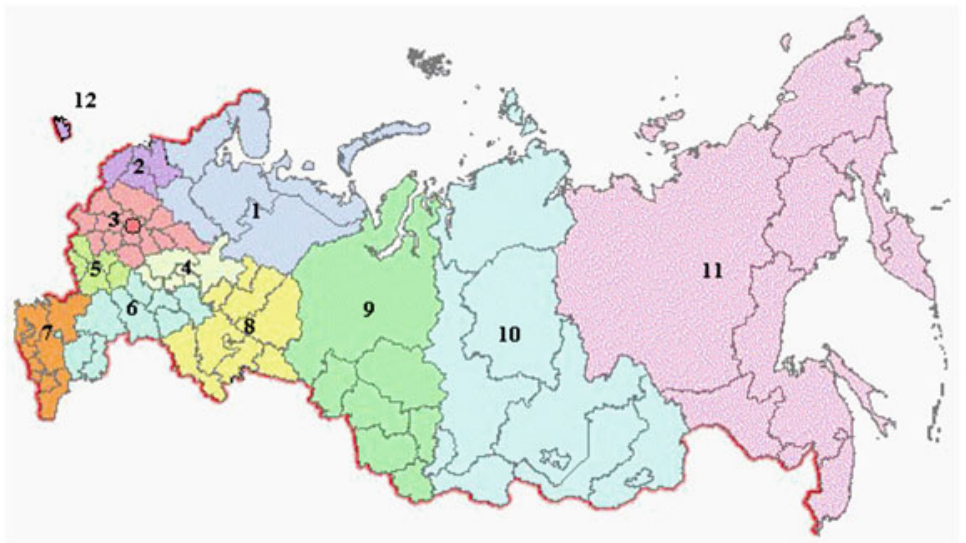

Fig. 3.1 Geographical overview of Russian engineering education

\footnotetext{
${ }^{1}$ Statistics (2016), http://aeer.cctpu.edu.ru/winn/ingobr/tvuz_main.htm.
} 
Table 3.1 Statistics of Russian engineering education

\begin{tabular}{l|l|l|c}
\hline$\#$ & Region & $\begin{array}{l}\text { Number of engineering } \\
\text { students in higher } \\
\text { educational institutions }\end{array}$ & $\begin{array}{l}\text { Number of } \\
\text { engineering students }\end{array}$ \\
\hline 1 & North region & 12 & 25,481 \\
\hline 2 & Northwest region & 24 & 123,386 \\
\hline 3 & Central region & 92 & 338,002 \\
\hline 4 & Volga-Vyatka region & 7 & 31,455 \\
\hline 5 & Central Black Earth region & 10 & 38,819 \\
\hline 6 & Volga region & 34 & 114,324 \\
\hline 7 & North Caucasus region & 21 & 81,650 \\
\hline 8 & Ural region & 23 & 103,071 \\
\hline 9 & West-Siberian region & 24 & 119,207 \\
\hline 10 & East-Siberian region & 20 & 66,462 \\
\hline 11 & Far East region & 6 & 28,039 \\
\hline 12 & Kaliningrad region & 1 & 4462 \\
\hline & Total & 274 & $1,074,358$ \\
\hline
\end{tabular}

\subsection{Regulatory Documents}

The system of state standardization of higher education program, acting from the mid-1990s, since the introduction of federal state standards (FSES 3), is relaxing strict regulation of the contents of education in the form of a specified set of subjects with a fixed amount of credits (state educational standards SES-1, SES-2), is now developing towards regulation of the structures of educational programs, conditions of implementation and results of learning (FSES 3, FSES 3+, in the long term FSES 4). For example SES-2 contained a cyclic structure:

- GSE cycle-general humanities and social-economic subjects;

- EN cycle-general mathematical and science subjects;

- OPD—general professional subjects;

- DS—specialization subjects;

- FTD_optional subjects.

The central place in SES-2 is taken by section 4 "Requirements to the compulsory minimal contents of the basic educational training program". This section includes a list of compulsory subjects for every cycle, their credit values in academic hours and a mandatory set of didactic units. 
Convergence of the national systems of education within the frames of the European Union is an important landmark in the global development of the higher school in the twenty-first century. The official date of the beginning of the convergence and harmonization process in higher education of European countries with a view to creation of harmonized higher education is considered to be June 19, 1998 when the Bologna Declaration was signed. Russia joined the Bologna process in 2003. As a result of this joining the educational process in most European countries is currently in the process of reforming. Higher educational institutions have set the task of not to unify but to harmonize their educational programs with others. In this connection, the state educational standards are undergoing rethinking and considerable changes.

With the introduction of the federal state standards of the third generation (FSES 3, 2011) Russian higher educational institutions gain greater independence in the formation of the major educational programs, choice of the learning contents, forms and methods, which enables them to compete on the market of educational services, and to respond to the demands of the labor market.

One of the major distinguishing features of the new standards is the competencybased approach. The essence of this approach is that the focus of the educational process is transferred from the contents of education to the results of studies which should be transparent, i.e. clear to all the stakeholders: employers, teachers, and students. The results of training are described by means of a system of competencies being a dynamic combination of knowledge, aptitudes, skills, abilities and personal qualities, which the student can demonstrate after completion of the educational program. The federal state standards of the third generation have inherited a cyclic structure. A major specific feature of the FSES of the higher professional education was the use of credits as a measure of the credit value of educational programs. The indicators of the credit value of educational programs, general speaking, the credit value of the cycles of subjects, are set in educational standards in credit units. For example, the aggregate credit value of the bachelor training is set at 240 credit units, Master training 120 credit units, specialist 300 credit units.

Just as "an academic hour", a "credit unit" is a unit of measurement of the credit value of academic work, but much more consistently oriented towards the work of the student rather than to the teacher. In all international and national systems there is a correspondence between credits units and hours. The method recommended by the Ministry of Education of Russia in 2002 establishes the equivalent of 1 credit unit to correspond to 36 academic hours. 
The central place of these standards was taken by the section with a list of study cycles, mandatory subjects for every cycle which regulated the credit value of every cycle in credit units and code of competencies formed in studying the subjects.

Another specific feature of FSES $3+$ is the introduction of the postgraduate program (postgraduate military course), residency training and assistantshiptraineeship into the levels of higher education.

Pursuant to 273-FZ, dated 29.12.2012, in developing the main curriculum an educational organization independently determines the distribution of the learning material by subjects and modules and establishes the sequence of their study.

The competency-based approach demanded comprehensive restructuring and modernization of the existing education system. Effective use of the competencybased approach is unthinkable without an adequate system of appraisal of every formed competency of the student determined by the state standard as mandatory for the particular educational program. Accordingly, there is need for development and introduction of the fund of means of appraisal allowing such an appraisal to provide a qualified conclusion regarding the conformity of the educational process to regulatory requirements. The need of the availability of such a fund with every educational organization is unequivocally enshrined in the Order of the Ministry of Education and Science of the Russian Federation dated 19.12.2013 No.1367 (revised on 15.01.2015): "20. Appraisal means are presented in the form of the fund of appraisal means for midterm assessment of the learners and for final (state final) assessment. 21. The fund of appraisal means for midterm assessment of learners in the subject (module) or practice included, respectively, into the steering program of the subject (module) or program of practice contains a list of competencies stating the stages of their formation in the process of study of the educational program; description of the indicators and criteria of appraising the competencies at different stages of their formation; description of the appraisal scales, standard assignments for submission or other materials necessary to appraise the knowledge, aptitudes, skills and (or) experience of activities characterizing the stages of formation of the competencies in the process of study of the educational program; guidance materials determining the procedures of appraisal of the knowledge, skills and (or) experience of activities characterizing the stages of formation of the competencies. For every result of study in a subject (module) or practice the organization determines the indicators and criteria of appraising the formedness of competencies at different stages of their formation and the appraisal procedures." The list of universal competencies has been approved by the Ministry of Education and Science of the RF. Universal competencies within the frames of the concept of modern education form the level of development of a specialist distinguishing a specialist with higher education from a specialist of a lower level. 
Besides, the methodological recommendations of the Ministry of Education and Science of the Russian Federation dated 22.01.2015 gear educational organizations to taking account of the requirements of the relevant professional standards in the creation of the basic educational programs.

Initially, FSES 3+ was to point to conformity to professional standards. The professional standard of a characteristic of the qualification necessary for an employee to perform a particular kind of professional activities. A professional standard is actually a document containing requirements to:

- the level of the employee's qualification;

- the experience of practical activities, education and learning;

- the contents and quality of the activities;

- the conditions of performance of the labor activities.

As of the moment of issue of FSES 3+ the professional standards in most fields of professional activities had not yet been approved; therefore, FSES 3+ could not formulate the graduate's professional competencies oriented towards generalized labor functions (kinds of professional activities) set by a concrete professional standard (PS). Analysis of the structure of the already approved PS has shown the impossibility to establish a mutually equivocal correspondence between fields of professional activities and educational fields. Therefore, "the core" of training has been identified in FSES 3+ in the form of universal (general culture) competencies and general professional competencies (independent of the particular kind of professional activities for which the learner is preparing and the focus (specialization) of the program). "The core" of training determines the "basic" part of the educational program which is quite fundamental and unalterable. "The variative part" of the program is oriented towards particular generalized labor functions or kind (kinds) of professional activities set by professional standards (if available). This part of the program is to be easily renewable and adaptable to new demands of the labor market. Figure 3.2 presents the structure of the list of education areas in the RF stating the number of consolidated groups of specialties and specializations included in every area of education and the number of such specializations.

Higher educational institutions are currently facing a crucial task: development of educational programs with account of the available professional standards, creation of adequate funds of means of appraisal. Of interest in this connection will be the available experience of the leading Russian universities in this area gained in the implementation of the international project 543851-TEMPUS-1-2013-1-DETEMPUS-JPCR (MetaMath) "Modern educational technologies in development of the curriculum of mathematical subjects of engineering education in Russia" and the Russian scientific-methodological projects "Scientific-methodological support 


\begin{tabular}{|c|c|c|c|}
\hline Basis - & Area of education & CGSS & ATS \\
\hline $\begin{array}{l}\text { harmonization } \\
\text { with European }\end{array}$ & $\begin{array}{l}\text { Mathematical and natural } \\
\text { sciences }\end{array}$ & 6 & 50 \\
\hline $\begin{array}{l}\text { approaches } \\
\text { (FOS 2007, }\end{array}$ & $\begin{array}{c}\text { Engineering, technologies } \\
\text { and technical sciences }\end{array}$ & 23 & 245 \\
\hline MSCO 2011) & $\begin{array}{c}\text { Healthcare and medical } \\
\text { sciences }\end{array}$ & 5 & 113 \\
\hline \multirow{6}{*}{$\begin{array}{c}\text { Introduction of } \\
\text { postgraduate program } \\
\text { (postgraduate military } \\
\text { course), residency training } \\
\text { and assistanceship- } \\
\text { traineeship into levels of } \\
\text { higher education }\end{array}$} & $\begin{array}{c}\text { Agriculture and agricultural } \\
\text { sciences }\end{array}$ & 2 & 30 \\
\hline & Social sciences & 7 & 65 \\
\hline & $\begin{array}{c}\text { Education and pedagogical } \\
\text { sciences }\end{array}$ & 1 & 11 \\
\hline & Art and culture & 6 & 94 \\
\hline & Humanities & 5 & 34 \\
\hline & $\begin{array}{c}\text { Defense and security of the } \\
\text { state. Military sciences }\end{array}$ & 2 & 21 \\
\hline
\end{tabular}

Fig. 3.2 List structure of education areas

of development of exemplary basic professional educational programs (EBPEP) by areas of education", "Development of models of harmonization of professional standards and FSES of higher education by fields of study/specialties in the field of mathematical and natural sciences, agriculture and agricultural sciences, social sciences, humanities and levels of education (Bachelor's, Master's, specialist degree programs)". Within the frames of grants working groups of Russian higher educational institutions developed exemplary educational programs of higher education in the modular format under the conditions of the introduction of "framework" federal state educational standards-FSES 3+ and in the long term FSES-4. The developers give practical recommendations for implementation of the competencybased approach in designing and implementing the educational programs. 


\subsection{Comparison of Russian and Western Engineering Education}

Given below is the comparison of Russian and western systems of education in terms of several formal features (such as the number of academic hours allotted for study of the Bachelor's degree program). This analysis certainly cannot be called complete; the contents of the educational program and the teaching quality depend on the particular higher educational institution and department. Nevertheless, such a comparison is to emphasize the greatest similarities and differences between educational systems in Russia and Europe.

The information as regards the structure of domestic educational programs is presented by the example of the curriculum of the field of Software Engineering of Ogarev Mordovia State University (OMSU) as one of the typical representatives of the Russian system of education. An example of a European technical university is Tampere University of Technology, TUT (Finland). The information has been taken from the TUT Study Guide; the authors were oriented towards the degrees of a Bachelor of Science in Technology and a Master of Science (Technology) in the field of Information technology (Tables 3.2, 3.3, 3.4, 3.5, 3.6, 3.7 and 3.8).

Table 3.2 Academic hours and credit units

\begin{tabular}{l|l}
\hline Russia (OMSU) & European Union (TUT) \\
\hline 1 academic hour $=45 \mathrm{~min}$ & 1 academic hour $=45 \mathrm{~min}$ \\
\hline $\begin{array}{l}1 \mathrm{credit} \text { unit }(\mathrm{CU})=36 \mathrm{~h} \text { (adapted to a } \\
\mathrm{CU} \text {-week term, weekly credit amount is } 1.5\end{array}$ & $\begin{array}{l}1 \text { credit unit (credit, cu, ECTS) }=262 / 3 \mathrm{~h} \text { in } \\
\text { Finland }(25-30 \mathrm{~h} \text { in different countries of the } \\
\text { EU) }\end{array}$ \\
\hline $\begin{array}{l}\mathrm{CU} \text { includes all kinds of student's work, } \\
\text { including independent studies }\end{array}$ & $\begin{array}{l}\text { ECTS includes all kinds of student's work, } \\
\text { including independent studies }\end{array}$ \\
\hline Credit value of 1 year $60 \mathrm{CU}$ & Credit value of 1 year 60 ECTS \\
\hline $\begin{array}{l}\text { The credit value of a subject is a whole } \\
\text { number (at least half-integer) of CU, i.e. a } \\
\text { multiple of } 36 \text { or } 18 \mathrm{~h}\end{array}$ & $\begin{array}{l}\text { Formally the credit value of a subject is a } \\
\text { whole number of ECTS, although it may be a } \\
\text { rounded off number (Discrete Mathematics): } 4 \\
\text { ECTS }=105 \mathrm{~h})\end{array}$ \\
\hline
\end{tabular}


Table 3.3 Freedom in choosing subjects

\begin{tabular}{|c|c|}
\hline Russia (OMSU) & European Union (TUT) \\
\hline $\begin{array}{l}\text { When entering the university the student } \\
\text { chooses both the department and the field of } \\
\text { study. Thereby the student invariably chooses } \\
\text { the greater part of subjects: both in terms of } \\
\text { quantity and volume of hours the selected } \\
\text { subjects make at least } 1 / 3 \text { of the volume of the } \\
\text { variative part. On average this is about } 1 / 6 \text { of } \\
\text { the total volume of academic hours (the } \\
\text { mandatory and variative parts are } \\
\text { approximately equal in terms of volume). } \\
\text { Choosing the educational program } \\
\text { specialization the student automatically makes } \\
\text { the decision on all positions of the } \\
\text { professional subjects as chosen }\end{array}$ & $\begin{array}{l}\text { When entering the university the student } \\
\text { chooses the study program. Orientation is } \\
\text { organized for first-year students before the } \\
\text { first week of studies. The student must (by } \\
\text { means of a special online-instrument) draw } \\
\text { up a Personal Study Plan approved by the } \\
\text { department. Most subjects are mandatory but } \\
\text { many courses can be freely chosen; the order } \\
\text { of their study is recommended but can be } \\
\text { modified by the student. The student enrolls } \\
\text { for the courses to get the necessary amount of } \\
\text { credits ( } 180 \text { for the Bachelor's degree } \\
\text { program, } 120 \text { more for the Master's degree). } \\
\text { Some courses or minors can be taken from } \\
\text { another higher educational institution (these } \\
\text { may be the so-called minor studies-see } \\
\text { below). The students have to annually } \\
\text { confirm their plans to continue their education } \\
\text { at the TUT (see below) }\end{array}$ \\
\hline
\end{tabular}

Table 3.4 Organization of the educational process

\begin{tabular}{l|l}
\hline Russia (OMSU) & European Union (TUT) \\
\hline $\begin{array}{l}\text { There are lectures and practical classes } \\
\text { stipulated in all subjects. The total share of } \\
\text { lectures in every cycle of the subjects (GSE, } \\
\text { EN, OPD + DS + FTD) is not more than 50\% }\end{array}$ & $\begin{array}{l}\text { Courses may contain only lectures or also } \\
\text { contain practical exercises, laboratory work } \\
\text { or work in groups. These exercises sometimes } \\
\text { are mandatory }\end{array}$ \\
\hline $\begin{array}{l}\text { The details of organization of the educational } \\
\text { process in every subject are given at one of the } \\
\text { first classes }\end{array}$ & $\begin{array}{l}\text { The details of organization of the educational } \\
\text { process in every subject are given at the } \\
\text { introductory lecture }\end{array}$ \\
\hline $\begin{array}{l}\text { Lectures are delivered to the whole class } \\
\text { (students of one specialization of training); } \\
\text { practical studies are conducted with students } \\
\text { of one group }\end{array}$ & $\begin{array}{l}\text { A lecture is delivered to all students that have } \\
\text { enrolled for the course. This also refers to } \\
\text { practical classes (if they are provided) }\end{array}$ \\
\hline $\begin{array}{l}\text { There is a possibility to be a non-attending } \\
\text { student }\end{array}$ & $\begin{array}{l}\text { There is a possibility to be a non-attending } \\
\text { student }\end{array}$ \\
\hline $\begin{array}{l}\text { A well-performing student is promoted to the } \\
\text { next course automatically }\end{array}$ & $\begin{array}{l}\text { A student must annually confirm the desire to } \\
\text { continue education }\end{array}$ \\
\hline $\begin{array}{l}\text { An academic year starts on 1 September and is } \\
\text { divided into two terms (autumn and spring). At } \\
\text { the end of every term there is an examination } \\
\text { period. The "net" duration of a term is 18 } \\
\text { weeks }\end{array}$ & $\begin{array}{l}\text { An academic year can start in late August } \\
\text { early September and is divided into 2 terms } \\
\text { (autumn and spring); every term is divided } \\
\text { into two periods (8-9 weeks each). The "net" } \\
\text { duration of a term is 17-19 weeks }\end{array}$ \\
\hline
\end{tabular}


Table 3.5 Grading system

\begin{tabular}{|c|c|}
\hline Russ & European Union (TUT) \\
\hline $\begin{array}{l}\text { Rating system ( } \max 100 \text { points). } 70 \% \text { of the } \\
\text { grade are gained during the term. The } \\
\text { aggregate rating is converted into the final } \\
\text { grade }\end{array}$ & $\begin{array}{l}\text { The rating system is not introduced at the } \\
\text { university as a whole; the current and } \\
\text { midterm performance is not always taken into } \\
\text { account (see above: there may be no practical } \\
\text { classes but sometimes they are stipulated, just } \\
\text { as mandatory exercises) }\end{array}$ \\
\hline $\begin{array}{l}\text { A 4-point scale is applied: } \\
\text { - Excellent: not less than } 86 \text { points out of } 100 \text {. } \\
\text { - Good: } 71-85.9 \text { points out of } 100 \text {. } \\
\text { - Satisfactory: } 51-70.9 \text { points out of } 100 \text {. } \\
\text { - Unsatisfactory: not more than } 50.9 \text { points } \\
\text { out of } 100 \text {. } \\
\text { Some Russian higher educational institutions } \\
\text { (primarily in Moscow, for example, MEPI) } \\
\text { introduced the ECTS grade system in their } \\
\text { institutions tying it to the student's rating. The } \\
\text { specific weight of the term may differ from } \\
70 \% \text { accepted at OMSU (for example, } 50 \% \text { at } \\
\text { KVFU) }\end{array}$ & $\begin{array}{l}\text { 6-point (from } 0 \text { to 5) scale is consistent with } \\
\text { the European ECTS: } \\
\text { - Excellent (ECTS-A): } 5 \text { points } \\
\text { - Very good (ECTS-B): } 4 \text { points } \\
\text { - Good (ECTS-C): } 3 \text { points } \\
\text { - Highly satisfactory (ECTS-D): } 2 \text { points } \\
\text { - Satisfactory (ECTS-E): } 1 \text { point } \\
\text { - Unsatisfactory (ECTS-F): } 0 \text { points }\end{array}$ \\
\hline $\begin{array}{l}\text { There are subjects in which "pass" and " } \\
\text { grades are given }\end{array}$ & ts in which "pass" and "fail" \\
\hline $\begin{array}{l}\text { If there are no grades below "good", with at } \\
\text { least } 75 \% \text { "excellent" grades and an } \\
\text { "excellent" grade for the FSA a "red" diploma } \\
\text { (with honors) is issued. Tests (all passed) are } \\
\text { not taken into account in calculation of the } \\
\text { grades }\end{array}$ & $\begin{array}{l}\text { If the weighted grade average is not below } 4 \\
\text { and the Master's thesis is passed with the } \\
\text { grade not below } 4 \text {, graduation with distinction } \\
\text { is issued. Tests are not taken into account in } \\
\text { the calculation of the average grade point }\end{array}$ \\
\hline
\end{tabular}


Table 3.6 Organization of final and midterm assessment

\begin{tabular}{|c|c|}
\hline Russia (OMSU) & European Union (TUT) \\
\hline \multicolumn{2}{|l|}{ Exams } \\
\hline $\begin{array}{l}\text { The timetable of exams is drawn up for a } \\
\text { group. The entire group takes the exam on the } \\
\text { same day }\end{array}$ & $\begin{array}{l}\text { Exams may be taken at the end of every } \\
\text { academic period. Students enter for an exam } \\
\text { individually }\end{array}$ \\
\hline $\begin{array}{l}\text { After a subject has been studied, the group is } \\
\text { to take an exam in it automatically }\end{array}$ & $\begin{array}{l}\text { In the case of desire to take an exam, the } \\
\text { student is to enter for it in advance (at least a } \\
\text { week before it is to be taken) }\end{array}$ \\
\hline $\begin{array}{l}\text { The "net" duration of an exam for every } \\
\text { student is generally about } 1 \mathrm{~h}\end{array}$ & $\begin{array}{l}\text { The "net" duration of an exam for every } \\
\text { student is generally about } 3 \mathrm{~h}\end{array}$ \\
\hline An exam is generally an oral answer & $\begin{array}{l}\text { An exam is a written work made on special } \\
\text { forms }\end{array}$ \\
\hline $\begin{array}{l}\text { The grade for an exam is determined right } \\
\text { after it is taken }\end{array}$ & $\begin{array}{l}\text { A teacher has a month to check the } \\
\text { examination papers }\end{array}$ \\
\hline $\begin{array}{l}\text { An exam is generally administered by the } \\
\text { teacher delivering lectures in the subject } \\
\text { (maybe together with an assistant conducting } \\
\text { practical classes). He is present at the exam } \\
\text { and gives the grade }\end{array}$ & $\begin{array}{l}\text { The exam is conducted by a special employee } \\
\text { of the university (invigilator); the teacher } \\
\text { delivering the course is not present. But all the } \\
\text { remarks made to the student during the exam } \\
\text { are recorded by the invigilator on his forms }\end{array}$ \\
\hline \multicolumn{2}{|l|}{ Final assessment } \\
\hline $\begin{array}{l}\text { The FSA (final state assessment) consists of a } \\
\text { state exam (at the option of the university) and } \\
\text { a graduation qualification paper }\end{array}$ & $\begin{array}{l}\text { In addition to Bachelor's thesis an exam in } \\
\text { the specialization (matriculation exam) is } \\
\text { taken and thesis is presented in a seminar. } \\
\text { Bachelor's thesis may be carried out as group } \\
\text { work; in this case it is necessary to state the } \\
\text { contribution of every student in the } \\
\text { performance of the assignment }\end{array}$ \\
\hline $\begin{array}{l}\text { In the Master's degree program the graduation } \\
\text { work is prepared in the form of a Master's } \\
\text { thesis } \\
\text { The final state assessment in the Master's } \\
\text { degree program may include a state exam }\end{array}$ & $\begin{array}{l}\text { In addition to a Master's thesis a } \\
\text { matriculation exam in the specialization is } \\
\text { taken and participation in a Master's seminar }\end{array}$ \\
\hline $\begin{array}{l}\text { A foreign language is included in the } \\
\text { mandatory part of the Bachelor's and Master's } \\
\text { degree educational program }\end{array}$ & $\begin{array}{l}\text { Foreign language is included as mandatory } \\
\text { part of Bachelor's degree }\end{array}$ \\
\hline
\end{tabular}


Table 3.7 Bachelor's degree program

\begin{tabular}{|c|c|}
\hline Russia (OMSU) & European Union (TUT) \\
\hline Period of studies 4 years & $\begin{array}{l}\text { Period of studies } 3 \text { years ( } 3-4 \text { years in EU } \\
\text { countries) }\end{array}$ \\
\hline $\begin{array}{l}\text { Total credit value of the main curriculum }= \\
240 \mathrm{CU}=8640 \mathrm{~h}\end{array}$ & $\begin{array}{l}\text { Total credit value of the main curriculum }= \\
180 \mathrm{ECTS}=4800 \mathrm{~h}\end{array}$ \\
\hline $\begin{array}{l}\text { B.1 GSE cycle: } 35-44 \mathrm{CU} \text {, with the basic part } \\
\text { of } 17-22 \mathrm{CU} \text { MSU: } 38 \mathrm{CU} \text {, with the basic } \\
\text { part of } 20 \mathrm{CU} \\
\text { B.2 MiEN cycle: } 70-75 \mathrm{CU} \text {, with the basic } \\
\text { part of } 35-37 \mathrm{CU} \mathrm{MSU}: 75 \mathrm{CU} \text {, with the } \\
\text { basic part of } 36 \mathrm{CU} \\
\text { B.3 Prof cycle: } 100-105 \mathrm{CU} \text {, with the basic } \\
\text { part of } 50-52 \mathrm{CU} \mathrm{MSU}: 105 \mathrm{CU} \text {, with the } \\
\text { basic part of } 52 \mathrm{CU} \\
\text { B.4 Physical education: } 2 \mathrm{CU} \\
\text { B.5 Practical training and on-the-job training: } \\
\text { 12-15 CU MSU: } 12 \mathrm{CU} \\
\text { FSA: 6-9 CU }\end{array}$ & $\begin{array}{l}\text { The core studies (basic or central subjects) } \\
\text { are the mathematical and natural science sub- } \\
\text { jects as well as other basic courses. The } \\
\text { objective is to familiarize the student with } \\
\text { basic notions in his field, to give the neces- } \\
\text { sary knowledge for further studies: } 90-100 \\
\text { ECTS. } \\
\text { Pre-major studies (introduction to the spe- } \\
\text { cialization): not more than } 20 \text { ECTS } \\
\text { Major subject studies are the subject deter- } \\
\text { mining the future qualification, including the } \\
\text { Bachelor's thesis: } 20-30 \text { ECTS } \\
\text { Minor subjects (other subjects) are additional } \\
\text { subjects but consistent with the future Bach- } \\
\text { elor's qualification: } 20-30 \text { ECTS. } \\
\text { Elective studies are not mandatory if the stu- } \\
\text { dent has fulfilled the minimal requirements of } \\
\text { admission for the study program. } \\
\text { Practical training is by the decision of the } \\
\text { department, not more than } 8 \text { ECTS. } \\
\text { Bachelor's thesis is an analog of the FSA: } 8 \\
\text { ECTS }\end{array}$ \\
\hline $\begin{array}{l}\text { There are subjects having no direct influence } \\
\text { on the future professional skills: the GSE } \\
\text { cycle, physical education. The university is } \\
\text { considered to train both a specialist and a } \\
\text { cultured person }\end{array}$ & $\begin{array}{l}\text { There are no humanities and physical } \\
\text { education. The university trains a specialist } \\
\text { only; all education is subordinate to this } \\
\text { objective. Matriculation examination can be } \\
\text { written in Finnish, Swedish or English }\end{array}$ \\
\hline Most subjects are fixed in the curriculum & $\begin{array}{l}\text { Most subjects are chosen by the student one } \\
\text { way or another }\end{array}$ \\
\hline $\begin{array}{l}\text { Practical training is a mandatory part of the } \\
\text { program }\end{array}$ & $\begin{array}{l}\text { The decision about the need for practical } \\
\text { training is made by the department }\end{array}$ \\
\hline $\begin{array}{l}\text { The volume of hours just for training of a } \\
\text { specialist (without GSE and physical } \\
\text { education): } 200 \mathrm{CU}=7200 \mathrm{~h}\end{array}$ & $\begin{array}{l}\text { All hours are allocated for training of a } \\
\text { specialist, their volume is } 180 \mathrm{cu}=4800 \mathrm{~h}\end{array}$ \\
\hline The volume of the MiEN cycle: $2520-2700 \mathrm{~h}$ & $\begin{array}{l}\text { The volume of Core studies (analog of the } \\
\text { MiEN): } 2400-2666.7 \mathrm{~h}\end{array}$ \\
\hline The volume of the Prof cycle: $3600-3780 \mathrm{~h}$ & $\begin{array}{l}\text { The volume of Pre-Major + Major + Minor } \\
\text { (analog of Prof): } 1066.7-2133.3 \mathrm{~h}\end{array}$ \\
\hline
\end{tabular}

Conclusion: Despite the availability of humanities the Russian Bachelor's degree program contains the same volume of basic knowledge (comparison of MiEN and Core studies) but substantially outstrips the Finnish by the volume of professional training 
Table 3.8 Master's degree program

\begin{tabular}{|c|c|}
\hline Russia (OMSU) & European Union (TUT) \\
\hline Period of studies 2 years & Period of studies 2 years \\
\hline $\begin{array}{l}\text { Total credit value of the curriculum }=120 \mathrm{CU} \\
=4320 \mathrm{~h}\end{array}$ & $\begin{array}{l}\text { Total credit value of the curriculum }=120 \\
\text { ECTS }=3200 \mathrm{~h}\end{array}$ \\
\hline $\begin{array}{l}\text { M. } 1 \text { General science cycle: } 23-26 \mathrm{CU} \text {, with the } \\
\text { basic part of } 7-8 \mathrm{CU} \\
\text { M. } 2 \text { Professional cycle: } 33-36 \mathrm{CU} \text {, with the } \\
\text { basic part of } 10-12 \mathrm{CU} \\
\text { M. } 3 \text { Practical training and research: } 48-50 \mathrm{CU} \\
\text { M.4 FSA: } 12 \mathrm{CU}\end{array}$ & $\begin{array}{l}\text { Common Core studies: } 15 \text { ECTS, including } \\
\text { compulsory } 7 \text { ECTS, complementary } 8 \text { ECTS. } \\
\text { There are several complementary subjects to } \\
\text { choose from; it is just necessary to get } 8 \\
\text { ECTS. } \\
\text { Major study (basic specialization): } 30 \text { ECTS } \\
\text { (in this case several variants to choose from) } \\
\text { Minor study (other subjects close to the spe- } \\
\text { cialization): } 25 \text { ECTS (in this case without any } \\
\text { choice). } \\
\text { Elective studies: } 20 \text { ECTS (this includes stud- } \\
\text { ies which cannot be included in other section, } \\
\text { for example, the English language). } \\
\text { Master's thesis-analog to the FSA: } 30 \text { ECTS }\end{array}$ \\
\hline $\begin{array}{l}\text { There are "general" subjects. Their volume } \\
\text { (M.1 cycle): } 828-936 \mathrm{~h}\end{array}$ & $\begin{array}{l}\text { There are "general" subjects. Their volume } \\
\text { (common core + elective studies): } 933.3 \mathrm{~h}\end{array}$ \\
\hline $\begin{array}{l}\text { Volume of the subjects of the prof. cycle: } \\
1188-1296 \mathrm{~h}\end{array}$ & $\begin{array}{l}\text { Volume of the subjects of the prof. cycle } \\
\text { (major + minor): } 1466.7 \mathrm{~h}\end{array}$ \\
\hline $\begin{array}{l}\text { Volume of Research work + FSA (M.3 + M.4): } \\
2160-2232 \mathrm{~h}\end{array}$ & $\begin{array}{l}\text { Volume of research work + FSA (Master's } \\
\text { thesis): } 800 \mathrm{~h}\end{array}$ \\
\hline
\end{tabular}

Conclusion: In the EU a Master's degree program more time is spent on training than in Russia (possibly because the volume of the Bachelor's degree program is bigger in Russia and Finnish Masters are still to be educated to the level of the Russian Bachelor's degree level). The research component in the degree is much stronger in Russia

Open Access This chapter is licensed under the terms of the Creative Commons Attribution 4.0 International License (http://creativecommons.org/licenses/by/4.0/), which permits use, sharing, adaptation, distribution and reproduction in any medium or format, as long as you give appropriate credit to the original author(s) and the source, provide a link to the Creative Commons license and indicate if changes were made.

The images or other third party material in this chapter are included in the chapter's Creative Commons license, unless indicated otherwise in a credit line to the material. If material is not included in the chapter's Creative Commons license and your intended use is not permitted by statutory regulation or exceeds the permitted use, you will need to obtain permission directly from the copyright holder.

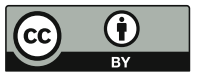

